\title{
Iran and Saudi Arabia's strategic rivalry and the Middle Eastern security: An assessment
}

\author{
Azeem Gul*1-2 | Rizwana Karim Abbasi ${ }^{1}$ | Syed Arslan Haider ${ }^{3}$
}

1. Department of International Relations, Peace and Conflict Studies, National University of Modern Languages (NUML), Islamabad, Pakistan.

2. Area Study Centre for South and North America, Quaid-i-Azam University, Islamabad, Pakistan.

3. Department of Management, Sunway University Business School, Sunway University, Malaysia.

*Corresponding Author Email: azeemgul@asc.qau.edu.pk

\begin{abstract}
The strategic rivalry between Saudi Arabia and Iran has been worsened for the last two decades. This historical sectarian divisions led by Saudi Arabia and Iran has now morphed into a struggle for regional influence between Shia political power led by Iran and Sunni political power led by Saudi Arabia. Against this backdrop, the study examines the contours of the Middle Eastern security in the context of Saudi and Iran strategic rivalry in various conflicts such as crisis in Syria, Yemen, and situation in Iraq including proxy wars and Iran's nuclear program. The study finds out that the security situation of the Middle East would have been much better if Saudi and Iran would have cooperated on various issues such as Yemen and Syrian crisis. In addition, the internal vulnerabilities of the Middle East with Iran and Saudi strategic antagonism provided opportunities to the external power intervention that further has intensified the conflicts in the region. The study concludes that the solution of the Middle Eastern problem would lie in building cooperation between Iran and Saudi Arabia relations and in this respect the current rapprochement between the two states is a positive development for Middle Eastern security.
\end{abstract}

\section{Article History}

Received:

March 7, 2021

Revised:

May 7, 2021

Re-revised:

June 11, 2021

Accepted:

June 21, 2021

Published:

September 12, 2021

Keywords: Middle East, Saudi Arabia, Iran, Syria, Iraq, Sunni political power, Shia political power, Strategic rivalry, Proxy wars, Security.

How to Cite: Gul, A., Abbasi, R. K., \& Haider, S. A. (2021). Iran and Saudi Arabia's strategic rivalry and the Middle Eastern security: An assessment. Liberal Arts and Social Sciences International Journal (LASSIJ), 5(2), 17-29. https://doi.org/10.47264/idea.lassij/5.2.2

Publisher's Note: IDEA PUBLISHERS (IDEA Journals Group) stands neutral with regard to the jurisdictional claims in the published maps and the institutional affiliations.

Copyright: () 2021 The Author(s), published by IDEA PUBLISHERS (IDEA Journals Group).

Licensing: This is an Open Access article published under the Creative Commons AttributionNonCommercial 4.0 International License (http://creativecommons.org/licenses/by-nc/4.0/) 


\section{Introduction}

The Middle Eastern region has been facing multifaceted challenges since the eruption of Arab Spring in 2010. One of the major factors to the present security crisis is the rivalry and mistrust between two major players is Iran and Saudi Arabia. Since the fall of President Saddam Hussain in Iraq in 2003 and the establishment of Shi'ite government in Iraq, the balance of power between Iran and Saudi Arabia has imbalanced. Further, the Yemen crisis has increased the power of the Houthis supported by Iran has further intensified Saudi's concerns about its regional influence. Iran also enhanced its collaboration with Qatar and Kuwait. This led to a rift between Saud Arabia and Qatar. The escalation between Iran and Saudi Arabia over Middle East has serious implications for regional security due to their proxies and alliances, yet more decades are still to come.

The rivalry over religious and historical connotation between these two actors has been evolved into the competition of geostrategic and geopolitical approach. However, the primary resistance source has embedded in the states national, economical, religious, political and military regard. Till 1970's, the pro-western realms, Iran and Saudi Arabia who had balanced relations before and remembered as a "twin-pillars" during the time of USA surpassing from British in the Persian Gulf. In the follow up, the square of Islamic (1979) and ushering of theoretical Shi'ite government lead by Ayatollah Khomeini where the conflict over ethnic framework took a new shape of regional robust in the region. By the time, a pessimistic view thoroughly is seen in the time of Shah of Iran when the virtual collaboration was at its peak.

\subsection{Current debate on Iran's and Saudi Arabia strategic rivalry}

Saudi and Iran have a key role shaping the Middle Eastern security arrangement. Iran from its part, bringing an end to Pahlavi dynasty and the establishment of Islamic Republic of Iran after revolution of 1979 has deep strategic consequences for the region and the Muslim world. The position of Iran along with Kingdom of Saudi Arabia (KSA) was seen as 'twin pillars' of Persian Gulf security during the cold war (Brannon, 1994; Zikriya 2019). For example, both monarchies were united by perceiving threats from Soviet Communism during the Cold War and the tide of Arab nationalism. Along these lines, as soon as KSA began to assert its position as a key oil provider leading to undermine Iran's role during the Arab oil embargo following the Yom Kippur war and an immediate effect on swelling of coffers. In Iran, the revolution brought changes in both the state's defence spending to reinforce the domestic control and regional position.

An important era of strategic rivalry between Iran and KSA is seen after the US invasion of Iraq in 2003. The invasion had seismic effects on Middle Eastern region and especially on Iran and KSA diplomatic relations. The US invasion of Iraq triggered competition with Iran that was supported by KSA. For example, Iraqi political leaders who were in exile in Iran returned to Iraq, which provided Tehran, a great deal of influence in the post-2003 Iraqi state (Dodge \& Bunton, 2004; Mahmood et al, 2020). Increasing Iran's influence has occurred much to the dismay of KSA which has urged the US "to cut of the head of the snake" (Gfoeller, 2008). The rivalry further increased when KSA with Israel discursively framing Iran an existential threat to regional security (Mabon, 2018).

In addition, Arab Spring revealing the schism between ruled, and ruler opened geopolitical competition in the region. The Arab uprising beginning in 2010 provided opportunities for both 
Iran and KSA. For example, Syria and Bahrain divided by sectarian lines provided a schism to both Iran and KSA to operate in pursuance of regional standing much at the expense of others (Mabon, 2018; Zehra et al, 2018). In case of Syria, elite Iranian troops helped in devising the Asad regime's strategy to defeat the protesters and other Islamist groups. Syrian security was badly affected till now. In case of Bahrain, KSA ordering its Peninsula Shield Force crossed the King Fahad gateway providing survival support to AL Khalifa ruling family against the Iranian activities (Mabon, 2012; Tayyab et al, 2020; Zehra et al, 2020). In addition, the Iran's rivalry was much intensified when US and KSA closely united by supporting Israel in case of recognition. The situation has further pushed the Middle Eastern security into another chaos (Hussain, 2020).

Recent improvement of Israel relations with Arab states have led to new trends in the Middle Eastern security. Within the context of strategic cooperation, Israel and UAE agreement would establish the process of normalization of relations much to the worries of Iran and more useful both for the US, Israel and Saudi Arabia. Experts have assessed that UAE and Israel agreement in non-military dimension would have spill-over effects to the military dimension of both states relations. As the agreement now encompass trade, technology, tourism, but the shared security dilemma from Iran, both Israel and UAE would explore cooperation in military areas. UAE has already indicated interests in Israel's Iron Dome Missile Defence System (Azodi, 2020). Purchasing of such advanced military technology from Israel will place Iran in precarious position in the Middle Eastern security arrangements.

Bahrain besides purchasing military weapons from Israel has also indicated interest in buying F-35 jets from the US. Bahrain by acquiring F-35 jets would become the second country in the Middle East with the world's most advanced fighter aircraft (Atwood \& Cohn, 2020). To this development, Iran has reacted negatively concerning its regional influence. Experts believe that Israel improving ties with UAE would contain Iran's regional influence. For example, the Iranian President Hasssan Rohani has reacted to the UAE deeper cooperation with the Jewish state. Rohani by responding to such development has warned the repercussion on Iran's regional security. Iran's top military commander Chief of Armed Forces General Staff (AFGS) major General Mohammad Baqri has also responded to Israel and UAE security cooperation that would change his country relations with UAE (Rasmussen, 2020). Besides, UAE, Bahrain, Oman improving relations with Israel, KSA has secretly cooperated with Israel against Iran by maintaining balance of power in the Middle East. Other Arab states security dilemma from Iran notably KSA has pushed seeking Israel support to contain Iran in the region.

\section{Theoretical context of the study}

Defensive realists admit that Saudi Arabia's current policies are defensive. Defensive realists write that the states remain defensive rather disturbing the balance of power in the system. States are primarily concerned with their position in the system (Waltz, 1979). Offense-defence balance favours the defence (Evera, 1998). It aims to maintain balance of power rather than upsetting the balance of power in the system. Shipping Tang writes that a state current defence is the realization of security dilemma and both states' leaders in this context do not pursue revisionist policies because to avoid counterbalancing alliances. Therefore, Saudi Arabia has behaved to adopt defensive policies (Tang, 2003). The adherence of both Iran and Saudi Arabia to the current world system reveals that they are not a revisionist power. Defensive realists admit that both Iran and Saudi Arabia have pursued defensive polices to avoid any confrontation or conflict in the system. 
Although, many experts believe that Iran and Saudi Arabia have defensive strategies if seen in this context but in both cases its security dilemma has led towards a competition for enhancing their capability to address their security threats. The rise of both states needs to maintain its sphere of influence in key strategic areas of Middle East such as Yemen and Bahrain, Iraq and Syria. On the other hand, Saudi Arabia has diversified its military resources to defend and maintain influence in the region. Waltz writes that defensive strategy of state aims not any maximization of power but to build up enough arms to counter the power of other state. Defensive realism dictates both Saudi Arabia and Iran to counterbalance each other by maximizing their presence in the region.

\section{Research methodology}

In this study we have used qualitative methods for data collection from various sources. For this purpose, current literature was surveyed. We have collected data from different online engines such as Google scholar, Google, PubMed, NCBI, online libraries (DRSM library, HEC digital library, Wiley online library). PDF Drive.Com. Further, the study is analytical and explanatory in nature based on literature review. The hypothesis of the study is predetermined and is not a testable hypothesis. Contrary to testable hypothesis, this predetermined hypothesis evolved through literature review is therefore a hypothesis leading to research. This hypothesis is interpretative and leading to research. The study has used active research method where during the process of research works of other experts and scholars was analysed to have a right research direction. The main argument of the study is that the Iran's rivalry with Saudi Arabia has led to undermining the security of Middle East as both states have security dilemma since the beginning of the $21^{\text {st }}$ century. The study is basically based on theory of defensive realism which helps in building the premise of the study that by maintaining the balance of power, the security of Middle East would remain stable. The major portion of data was collected from secondary sources such as books, research articles from journals, newspapers, and reports. For this study, all the data was analysed, and proper references have been given. All the research ethics was followed to avoid any plagiarism.

\section{Analysis and discussion}

\subsection{Factor shaping Iran and Saudi Arabia strategic rivalry}

\subsubsection{Political factor}

The complex security issues and strategic environment between Saudi Arabia and Iran ties are mainly to sustain a balance of power in the scope of political, religious and economical effect in these regions. However, both actors are in the race to acquire hard and shift status or power in each other domains. Their blowing resentments have been grown towards foremost foundations in the circle of regional power antagonism they have been tangled in for long. Most importantly, the struggle of power indicates indirect proxies and ideological diffusion. Here, escalating the effect in power struggle is not precise but dimension is spread throughout intraregional, non-state and extra-regional, resolute, irresolute, direct/indirect/ and other parties of enmity (Ersoy, 2013).

Despite the fact, scrutinizing the strategic competition in context of investigation, the locals of Saudi Arabia tried to incorporate with minorities of Shi'ite. Apparently, in January 2016, proved to be rigid that could be unauthorized by the performance of Shi'ite clerics known as 
Nimr-al-Nimr. Hence, bilateral diplomatic ties provoked to be frenzy and raged in Iran dissolution by this act. Similarly, intervention in Yemen civil war occurs by Saudi Arabia leadership decision indicated assertive strategy towards priest of Shia in the entire state (Slawson, 2016).

Therefore, the balance of power is denoted as the cold war between both rival regional powers. In this proximity of secular conflict both Iran and Saudi Arabia are in new arena of resilient collaboration and regional companions. Focusing on the new cold war era between the two countries and its changing dynamics, better analysis can be taken from overviewing of the connotations at domestic and regional level, transnational relations, domestic conflicts and regional configurations are overlying and intertwined. The main reason behind the entire environment created in the Middle Eastern region is weak foundations and structure of the Arab world in ideological upgrading and religious factors as compared to sectarian division. In this notion, the most significant in the contemporary chaos and unstable political arrangements in the Arab are Syria and Yemen conflict, the probability of long-term war is more in the limelight (Ighani, 2016).

Yet the absurdity of power politics is mainly the most focused in strategic competition of the entire Middle East. Notwithstanding, lacking in the capabilities of military equipment are reasonably inadequate in the proxy wars which are utilized as an instrument to support the nonstate elements in local political conflicts. But in order to have resilient alliances, enough patronage of regional alliance demands, ideological transnational and political social structure are likely to create possible negotiations in building ties with the benefactor. In common terms, states are engaged in receiving threats from other countries as they have connections and links to gain their national objective (Pervin \& Spiegel, 2014).

The religious characteristics curtail ideational gaps and self-identification of groups intricate in religious identities to definite evolution or dogma. In rational standings, Iran illustrates to be a non-Arab known as Shi'ite country which as historical ties with Persian civilizations (Daryaee \& Daryayi, 2012). On the other side, the ideologies identify by Saudi's are Salafism also known as Sunni sector. As a result, these two conflicting blocks framed as ideational rifts has dichotomized the states. Briefly, as the illogicality of resentment and ideational between Iran and Saudi Arabia gives a specific logic, by deliberating legitimacy in their pursuit of policies entirely in the region by means of capitalization the material and immaterial along with increase in the support with alliances force and other countries. With a tricky action of Iran binding up with Lebanon (Shaery-Eisenlohr, 2008) and Iraq, effectiveness in the region is going to reach towards further extend by three authorized developments. One is building up of Shi'ite central government in Iraq by the support of Iran (Barzegar, 2010). Secondly, as the escalating protests in Saudi Arabia against the government has mounted to be supposed as a predominant threat by the Kingdom of Saudi Arabia. Lastly, the sudden Syrian crisis and Assad's regime backed by Iran had immensely undermined the region.

Hence, the entire Middle East is involved in turmoil because of its inclination to influence many securities. The strategic competition and ideological conflict between Iran and Saudi Arabia along with their drawbacks have ultimate impacts in order to have long-term repercussions not only within but internationally as well. Not neglecting the fact of where Syrian civil war is still in limelight in the international arena has pictured the condition onto more worst circumstances in term of security too. 


\subsubsection{Economic factor}

Economically, both Saudi Arabia and Iran are rich in the resources of oil market, which evolves another competition. Undoubtedly, KSA and Iran are expanding their business through oil producing and reserving status in Organization of Petroleum Exports Countries (OPEC) (Cooper, 2012). During the post-nuclear rapprochement time, Iran had advantage over open oil markets to energy countries and that is the reason of commodity came to foremost inference in the competition of oil market in Middle Eastern region. The motivations economically consequently risen up the strategic competition between them. Contrarily, in the means of power struggle and sources of material competition between Saudi Arabia and Iran, geopolitically position of Middle Eastern region, ideational, immaterial and religious outcomes created the complexities more worsen.

\subsubsection{The military factor}

In the context of military, peaceful use of nuclear weapons claimed by Iran in their nuclear ambitions are acquired as a concern of destabilization for Saudi Arabia. By upgrading of nuclear use, which is Saudi Arabia's main concern of security itself from the strategic rivalry environment of the region (Pasha, 2016). Pressures from regional level and internal exposure like United States provide validation for Iran by having synchronized military up-gradation (Bruno, 2010). Not denying the fact that strategic contest between both is immensely taking place towards pivotal limitations socially, economically and politically and at the military by taking hold of all these in the Middle Eastern region. For the most part, the adversaries strategically gain the international influence, power of struggle and security dilemma. In the rise of democratic values during Arab Spring and shifting of dynamics of Middle Eastern region has terrifically changed the nature of coming threats, the non-state actors were capable in the state system and the occurrences of international terrorism came as a new rootling thought. Further, the regional security order of Middle east was also transformed from bi-polar to tri-polar order where Turkey also added a new major new actor.

The abysmal effect of security dilemma derived from local groups likely to be against statusquo factor as well as determinably volunteers to make the regime into something else. This will go in the indulgence of Saudi and Iran to alleviate dilemma of insecurity and to that reason it would become stable the regime and made worthy at state equal. Undeniably, there are number of states which still stay at the part of conflict in all states of Middle Eastern region.

Major cause of resistance between Saudi Arabia and Iran is security dilemma. Though, security dilemma has its own importance when the questions come in states sovereignty and that is reason security dilemma becomes insecurity dilemma. When external threats are received, security within the internal regimes states exploits (Huwaidin, 2015). For this reason, both are playing smartly to direct an effective regime even at the cost of internal insecurities. Keeping in view the strategic rivalry between both entities, their insecurity of regimes within respective countries persuades them in order to deter the national insecurity towards their foreign relations, sponsors, create or exploit on international skirmishes, by the means to elucidate inner security, regimes, a tough degree of insecurity worldwide. In order to make certain changes in the security by insecure regimes within the state, there should be a cooperative significance of insecurity dilemma tends to have wide opportunity and profound possessions for Iran and Saudi Arabia involvement in regional conflict internationally (Mabon, 2013). 


\subsubsection{Emergence of proxy war}

There is no repudiating the circumstances that Saudi Arabia and Iran does not have rivalry for the ground time to encourage the Middle Eastern region. Resultantly, in 1978 when the Shah Muhammad Reza Pahlavi of Iran just about mislaid his leadership, meanwhile two Yemeni states were involved in war against each other for regional domination and in the instant Israel and Egypt contracted a peace treaty. However, the crisis in Middle Eastern of Syria and Yemen proxy wars is a prior affected to endorse the strategic competition among Iran and Saudi Arabia. Meanwhile, the tactics of previous cold war clouded in the shape of political backdrop in some other countries within the region as well, including Lebanon, Iraq and Bahrain along with the prolong conflict in Yemen and Syria have a true significance. Here, the major rule of international exposure on sectarian outlines escalated for Iran and Saudi Arabia and created more influence in terms of sectarian logic of war which is a new era of conflict apart from resources (Abboud, 2018; Mahmood et al, 2020).

Understanding the viewpoint if opposition who are expected to perceive the milieu as impartial in the start of proxy war refrain themselves in embracing the secular interpretation. Hence, a massive effort to neglect or name it as sectarian issue and articulate a non-sectarian outcome of the Syrian war with a clear image without Assad's regime. After a while, the change in their strategic thinking came in front by support of Arab countries in economic terms ensued in a great benefit headed for Iran and Saudi Arabia strategic competition and could enable the conflict for even more years. It is known that because of Assad's regime, all the conflict framed as a political tension between the opposing bodies and other competing groups. Notwithstanding the fact that like other autocratic regimes of Arab states i.e., Egypt and Libya, Assad desired this to come in certain conclusions, in order to provoke his own leadership; he acquired the option to use force. Accordingly, the reaction from civilians were not what Assad expected, intensified towards moderate and aggravated into a complete civil war. The whole setting grew its attention in international arena by superpowers. Likewise, Russia and Iran, gave the clear impression of supporting Assad's regime, although the countries in the western front like Turkey and Saudi Arabia were confused by the assistance of adversary's action (Khan, 2020; Micallef, 2013).

Now, apart from free Syrian Army, Radical movement like Salafism per Sunni Islamist paramilitaries in the practice of Jabhat-ul- Nusra were also playing a vigorous role. In terms of authorization, they were unlawful groups like insurgents, associated with terrorists who had a direct link with Al-Qaeda. This was for all the instant view of whole democratic and political conflict cycle in the Middle Eastern region where on the one side affiliated with Shi'ite Muslims and on other Salafism Muslims. Intentionally, it is known for strategic competition in the entire Middle Eastern Region specifically for Iran and Saudi Arabia (Furtig, 2014).

To tumble down the contemporary regime filled with harsh realities, Riyadh came out to pave the way for effective policies by shifting it with Sunni led regime by having good terms with Saudi Arabia. The history witnesses the friendly relations of Iran and Syria along with having good relationship with other Shi'ite led countries. Evidently, their relations were recorded as to be in financial, political and strategically united. According to some scholars and their common beliefs illustrates thee nature as if collaboration and alliances started in 1980's known as Islamic revolution in Iran and its establishment, and they have been defensive from the beginning. Additionally, a new era of aggressive posture during 1980's and 1982 was seen between Iran and Syria, embarked by Iraq and Israel correspondingly. Though, both countries 
are envisioned to offset and fight Turkey in the region. It is acknowledged that Turkey is the member of North Atlantic Treaty Organization NATO and backed strongly by the United States allows to have a dominant position and Syria ideologically threats from it. In contrast, Iran had alliance with Russian Federation at that time and now both of them have mutual rivals i.e., Israel, USA and Saudi Arabia. Both Iran and Saudi Arabia is unexpectedly suspected for their support to various activities and organizations together with individuals who are labelled as terrorist's group in United States and Europe.

So far, the provision in both the circumstances is supposed to be ideologically driven. It is thought that Saudi Arabia upheld its genial affairs with Wahhabis and Islamic State despite the fact that Iran is frequently allied with Hezbollah and Hamas. Hence, Saudi Arabia natives are maintained by the prior radical organization by or devoid of recognition from their kingdom. Here, Iran is aware about upsetting with worldwide openness and further concerned with their own model of Islamic governance, although on the other extreme Saudi Arab at the end of 1920's undertakes such sympathetic of stances that time the Saudi Arabia were enforced and these days they cannot dichotomize themselves from Wahhabi slogan in the region and abroad. The ideological initiated variance among Iran and Saudi Arabia; Sunni Hamas had not intangible back by Iran known to be Prima Facie case of the scenario that there is a probability of displaced benefits in the sectarian outlook of separation. Iran's provision to Palestine and the burdened community is one of the key fundamentals of its foreign policy and one of the protuberant shares of its authorized ideology. Even though it would not be an overstatement to elaborate that Iran inclines to understand the Palestine issue as a beset state as well (Zahoor \& Sadiq, 2021).

The uplift of Sunni radical organization in the Middle Eastern region seemed to have an existential threat to all the Shi' ite community, in specific, Iran. During 2014, subsequently its positive military operation in Iraq, called as Islamic State has modelled perceptible intimidations to Iran also. The confiscation of Mosul by the antagonistic organization which is the second biggest city of Iraq is a significant danger to Iran. Currently, the Iranian safety formations have no other choice left behind nonetheless, battle vigorously and frighten the Terrorists. To know circumstances to Iran that formation of Daesh was a conception of Takfiris and to undermine and enthusiasm of Assad regime, arms funding was delivered by United States and Saudi Arabia, for the only motive to divide and mechanism of Iraq and their oil resources (Plebani, 2017).

The luck was not their because connection with ISIS to Saudi Arabia along with the other ongoing conflict in Syria and Iraq made the status quo deteriorated and relation of both as well. In order to deter and fight against ISIS, it had better be official for Saudi Arabia and Gulf States to lead their ground troops to Syria and Yemen, indeed the actual reason behind it would be to back Anti-Assad regime (Osiewicz, 2016).

\subsection{Iran's nuclear expansion: Regional security risks}

The new era of nuclear development, Iran possession in the nuclear strategies grew and an old international tie over nuclear program is one of the most significant in all the security challenges, came to a limelight. Not neglecting the Iran's serious contribution in the important Middle Eastern Subjects and its geostrategic position, such kind of expansions could associate the forthcoming command of Middle Eastern region. The nuclear deal of Iran is very substantial not only for international security and non-proliferation regimes but similarly for wider Middle 
East as a complete. The reason behind cold war and command and control is their nuclear capabilities which hold an important factor to realize it as the key state of Middle East. In order to procreate regional battles from Iraq, Lebanon, and Syria to Yemen, the illogicality between these protuberant regional actors helps as the security and geopolitical contextual upon which the nuclear deal was gathered. In this way, the strategic competition advance, regardless of the information whether it is achieved and determined efficiently or not, or possibility to intensify and control the landscape of' the security subtleties of Middle East for upcoming years. Widely held by the political analyst, be certain of that Iran nuclear deal could alleviate the perceptible perils of proliferation and acclaimed the expenditure of the source. Hence, the evolution of Weapons of Mass Destruction (WMD) to be free zone which could be hypothetically progressive in the region by engaging in the deal. In the antagonistic approach to this, numerous social scientists conveyed their interpretations for the conflicting consequences of the agreement. It is to be seen that Iran's drive in the direction of proliferations and regional weaponization had extensive uncertainties and will enhance nuclear arms race in Arab states particularly in United Arab Emirates and Saudi Arabia, which have by now boarded on a category of peaceful nuclear program (Shirley, 1994).

Within the same way, the region will be involved in a warm sort of cold war where a war of fascination among the subordinates will win, like what we saw in Iraq, Syria and Yemen. The nuclear deal of Iran postures existential dangers to Middle Eastern states in its control projection, back for ballistic Missiles and arsenals are foremost. The stability and security of region can only be ensuring by Iran's nuclear posture in the current arena in order to restrain their foreign agendas in the sector of economics could negate as the major tool in this regard. In the viewpoint various strategic thinkers enumerate their expression in Iran's economical outreach and due to the threat perils and expensive regional ongoing conflict, there could be chance to back down the relationships in the region.

Now, as there is a dire need to have collaboration among different states, Iran is taking its full advantage to reinforce and fortify its ties within the Middle East. Iran's foreign policy for instance is having an impact within the region and outside by forging the new internal conflicts and its challenges in the Islamic Republic could set free as a result of nuclear engagements. Despite the fact, conflicting to Iran's economic growths and regional economic incorporation will not be in a place to distract the country from its existing foreign policy trail. To engage in conspiracy of disagreements in Middle Eastern region, Iran has the dimensions to do so, somewhat its nuclear deal is an actual inconsistency in this characteristic. From side to side, the implements of ferocity, discontent and disorder outer in its edge of Iran's nuclear deal unceasingly perceive its delays. However, fierceness and resentment of the Arab states could deteriorate Iran's position in the Middle Eastern region. Subsequently, nuclear deal in the Arab states is more susceptible as linked to Iran; the mounting unpredictability and less effectiveness in the Arab countries could most possibly prime to the political divergence of Gulf Cooperation Council (GCC) at the hands of Iran. As a product of the nuclear deal a supplementary angle in the region, balance of power on the way to Iran is conceivable, that's how Gulf States would be reliant on more on the outside security necessities (Milani, 1994).

Similarly, the territorial politics in Saudi Arabia and its territorial Middle eastern partners would endeavour difficult, yet to overcome the shortcomings, terrible divisions and move back the adjust towards the Middle eastern world. As the bargain with the growing Iranian impact within the region, its pair with rise and given territorial turmoil, the non-Arab states are conceivable in case of territorial coordination and Arab-Turkey key organization. Additionally, 
both Iran and Saudi Arabia strategic competition is more likely to heighten and emphasize the area of dispute within and coming years which incorporate its covert back to the proxy wars, battling within the Middle Eastern region. By means of that Iran is battling to combat Saudi Arabia through these groups in Iraq, Syria, Bahrain, and Yemen in proxy wars. Although the Kingdom of Saudi is additionally accused of its affirmed help and backing to the proxy groups restricted to Iran's posture within the region, but it isn't as solid involve as Iranian back. In the time when Saudi Arabia had weak position in maintain relations past in 25 years with Iraq, she tried to intervene into state's internal affairs which could have make ways for Saudi policies. As both the performing actors were not intricate straightforwardly within the Iraq conflict, Iraq government since Nimr Al-nimra killing in January 2016 has publicized to intervene between the two key competitors over expanded pressures.

The efficacy was seen in the conflict of Syria by both Iran and Saudi Arabia which incorporated Saudi Arabia reinforcement for Salafi Jihadist militia. They were associated with Jabhat Fateh Al-Sham (once Al-Nusra front) and Al-Qaeda on the other. Iranian support which incorporates the Lebanese Hezbollah. Saudi Arabia engaged its troops by sending its Arms and ammo to rebel groups in Syria whereas, on the other side, Iran sent the Revolutionary Guards corps personnel's there as well. In early 2015, the Houthis got the most extreme control of Yemen and yet, Saudi Arabia government forces are waging a military campaign in Yemen against the rebels. By combating Iranian Shiite hegemony on Southern border Saudis are defensive in Yemen's war as they have faith in Iran to be directly assisted by the Houthis. The Figure below has provided the current Yemni situation.

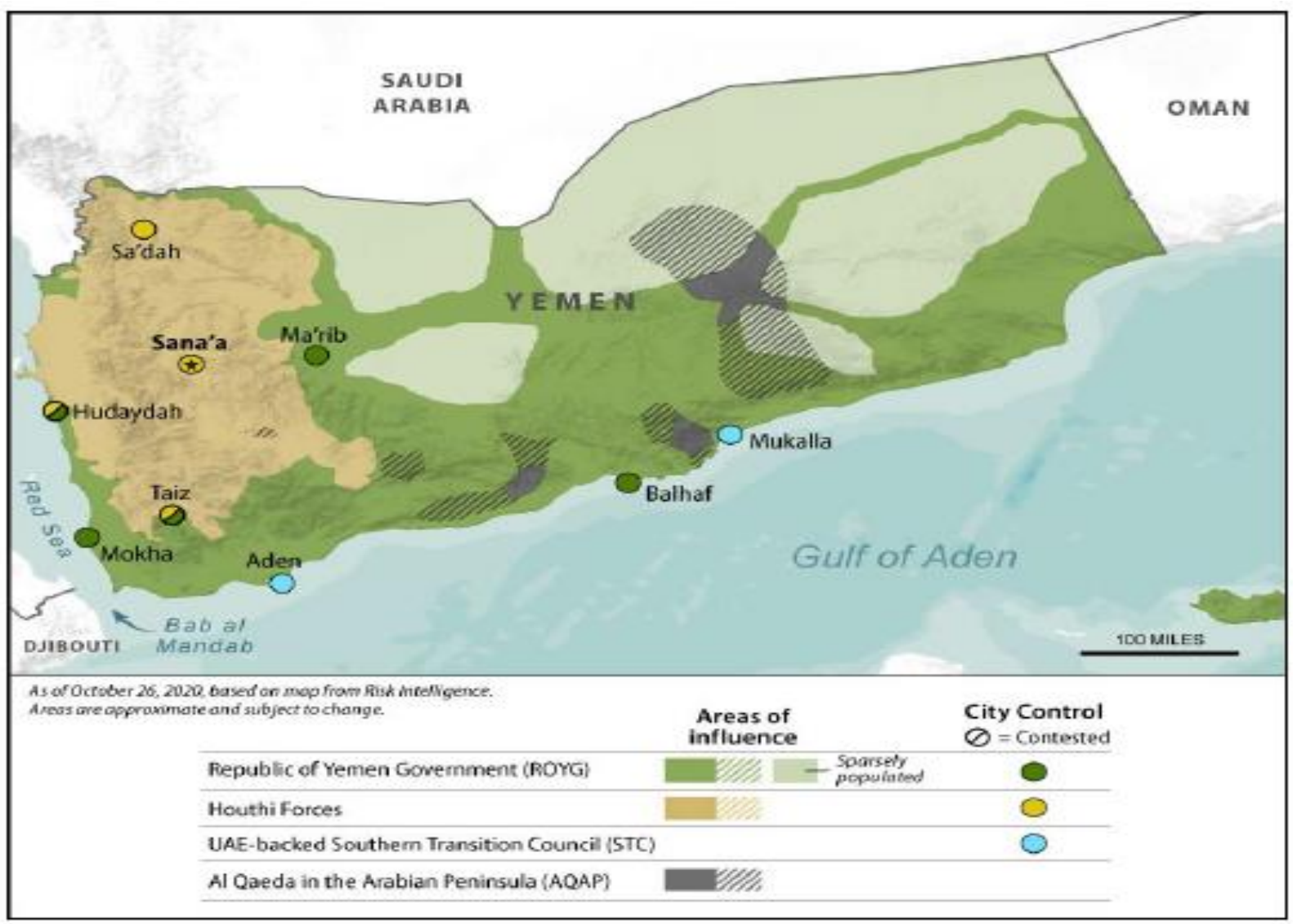

Source: Graphic created by CRS using data from Risk Intelligence (2020); Esri (2017 \& 2018); NOAA (2018); USGS (2018); Department of State (2015). 
Besides Yemen, Bahrain is another grey area of Saudi Arab-Iran proxy war somewhere Sunni sovereign regulate the Shiite majority. In 2011, Saudi suspected that Iran lured marches at the command of Bahrain royal family, which employed the impact Saudis and Iranians endured to spat over Bahrain and reproving each other for inquisition of country's internal dealings.

\section{Conclusion}

The Iran-Saudi Arabian strategic rivalry has been discussed in the context of Middle Eastern security situation with reference to Iraq, Syria, Yemen, proxy wars along with nuclear issue of Iran. Further, the study has also discussed the factors that led towards intensification of security situation in the Middle East. The study finds out that one of the main causes of instability in the Middle East is due to Iran's and Saudi Arabia strategic competition at the political, economic and military domains. From the political angle, both states have different ideological and political construct. Scoring from the political perspective, the Iran and Saudi Arabia strategic rivalry is due to different political culture with different experiences. For example, in case of Iraq, both states are contrasting when Iran has influenced government which was formed in Iraq. The same is followed in Syria where political differences have led to supporting different proxy groups and at the international level where the US is supported by Saudi Arabia against Iran. However, the other powers such as Russia in one way or another has supported Iran. Against this backdrop, political dichotomy has existed to the level where the security of Middle East has undermined.

The security of Middle East viewing with the economic perspective, economic competition between Iran and Saudi Arabia has led to strategic competition. Iran has feared since Saudi Arabia has increased its oil expansion. Of these two broader security dynamics, Saudi and Iran military rivalry has also intensified in the form of Yemen conflict particularly. For example, Iran's nuclear is a good issue where Saudi has adopted opposing Iran's nuclear development because Saudi Arabia has adopted and shaped by acquiring the most advanced military weapons from the US through the Arms trade deal during the US President Trump era from America. The same was followed by Bahrain, Oman and other Middle Eastern states due to its perceived security dilemma from Iran. The Middle Eastern security would have been remained stable if Iran along with Saudi Arab has cooperated in areas of more political dynamic would have then opened avenues for cooperating at the economic and military affairs. By highlighting current security situation in the Middle East, the current study would be useful for policy makers and other academics how and why the broader context of security has been chaotic in the Middle East.

\section{Declaration of conflict of interest}

The author(s) declared no potential conflicts of interest(s) with respect to the research, authorship, and/or publication of this article.

\section{Funding}

The author(s) received no financial support for the research, authorship and/or publication of this article. 


\section{References}

Abboud, S. N. (2018). Syria: Hot spots in global politics. John Wiley \& Sons.

Atwood, K., \& Cohn, Z. (2020, August 20). Kushner's secret push to sell F-35 jets to UAE causes frustration among US agencies and lawmakers. CNN Politics. https://edition.cnn.com/2020/08/20/politics/kushner-uae-israel-f-35-fighterjet/index.html

Azodi, S. (2020, August 20). Why is Iran concerned about the peace agreement between the UAE and Israel? Atlantic Council. https://www.atlanticcouncil.org/blogs/iransource/why-is-iran-concerned-about-thepeace-agreement-between-the-uae-and-israel/

Barzegar, K. (2010). Iran's foreign policy strategy after Saddam. The Washington Quarterly, 33(1), 173-189. https://doi.org/10.1080/01636600903430665

Brannon, S. (1994). Pillars, petroleum and power: The United States in the Gulf. The Arab Studies Journal, 2(1), 4-10. https://www.jstor.org/stable/27933629

Bruno, G. (2010, March 10). Iran's nuclear program. Council on Foreign Relations. https://www.cfr.org/backgrounder/irans-nuclear-program

Cooper, A. S. (2012). The oil kings: How the US, Iran, and Saudi Arabia changed the balance of power in the Middle East. Simon and Schuster.

Dodge, T., \& Bunton, M. (2004). Inventing Iraq: The failure of nation building and a history denied. International Journal, 59(3), 737-739. https://www.proquest.com/openview/ee8e2b5c145ded1328ec774c2b17f9b9/1?pqorigsite $=$ gscholar $\& \mathrm{cbl}=40991$

Daryaee, T., \& Daryāyī, T. (Eds.). (2012). The Oxford handbook of Iranian history. OUP USA. Ersoy, E. (2013). The rivalry between Saudi Arabia and Iran in the Middle East. USAK Yearbook of Politics and International Relations, (6), 295-298. https://www.ceeol.com/search/article-detail?id=319379

Evera, S.V. (1998). Offense-defense and the causes of war. International Security, 22(4), 5-43.

Furtig, H. (Ed.). (2014). Regional Powers in the Middle East: New constellations after the Arab revolts. Springer.

Gfoeller, M. (2008, April 20). Saudi King Abdullah and Senior Princes on Saudi Policy toward Iraq. Declassified Cable through Wiki Leaks.

Hussain, Z. (2020, November 25). Recognizing Israel. Dawn News. https://www.dawn.com/news/1592222

Huwaidin, M. B. (2015). The security dilemma in Saudi-Iranian relations. Review of History and Political Science, 3(2), 69-79. http://rhpsnet.com/vol-3-no-2-december-2015abstract-8-rhps

Ighani, H. (2016, October 24). Managing the Saudi-Iran rivalry. Council on Foreign Relations. https://www.cfr.org/report/managing-saudi-iran-rivalry

Khan, R., Mahmood, A., \& Salim, A. (2020). Arab Spring Failure: A Case Study of Egypt and Syria. Liberal Arts and Social Sciences International Journal (LASSIJ), 4(1), 44-53. https://doi.org/10.47264/idea.lassij/4.1.5

Mabon, S. P. (2018). Saudi Arabia and Iran: The struggle to shape the Middle East. https://eprints.lancs.ac.uk/id/eprint/129059

Mabon, S. (2012). The battle for Bahrain: Iranian-Saudi rivalry. Middle East Policy, 19(2), 8497.https://www.proquest.com/openview/7dfbe9aa4a983587cff7986920e10357/1?pq -origsite $=$ gscholar \&cbl $=31168$

Mabon, S. (2018). Muting the trumpets of the sabotage: Saudi Arabia, the US and the quest to 
securitize Iran. British Journal of Middle Eastern Studies, 45(5), 742-759. https://doi.org/10.1080/13530194.2017.1343123

Mabon, S. (2013). Saudi Arabia and Iran: Soft power rivalry in the Middle East. IB Tauris.

Mahmood, A., Wajid, S., \& Sherazi, T. Z. (2020). Impact of Arab Spring on Egypt: An Analysis of Opportunities and Challenges. Journal of Humanities, Social and Management Sciences, 1(1), 30-43. https://doi.org/10.47264/idea.jhsms/1.1.3

Mahmood, A., Munir, F., \& Naomi, S. S. (2020). The Plight of a Nation without a State: An Analysis of the Struggle of Kurds for an Independent State. Liberal Arts and Social Sciences International Journal (LASSIJ), 4(2), 400-412. https://doi.org/10.47264/idea.lassij/4.2.31

Milani, M. M. (1994). Iran's post-cold war policy in the Persian Gulf. International Journal, 49(2), 328-354. https://doi.org/10.1177\%2F002070209404900207

Micallef, J. V. (2013). Islamic State: Its history, ideology and challenge. Anitoch Downs.

Osiewicz, P. (2016). Ideological determinants of the current Saudi-Iranian rivalry in the Middle East. Przeglad Politologiczny, (2), 115-125. https://www.ceeol.com/search/articledetail?id=472476

Pasha, A. K. (2016). Saudi Arabia and the Iranian nuclear deal. Contemporary Review of the Middle East, 3(4), 387-404. https://doi.org/10.1177\%2F2347798916664613

Pervin, D. J., \& Spiegel, S. L. (2014). Practical peacemaking in the Middle East: Arms control and regional security. Routledge.

Plebani, A. (2017). After Mosul: Re-inventing Iraq. Ledizioni.

Rasmussen, E.S. (2020, August 16). Israel-U.A.E. diplomatic deal ratchets up tensions with Iran. The Wall Street Journal. https://www.wsj.com/articles/israel-u-a-e-diplomaticdeal-ratchets-up-tensions-with-iran-11597592210?redirect=amp

Shaery-Eisenlohr, R. (2008). Shi'ite Lebanon: Transnational religion and the making of national identities. Columbia University.

Shirley, E. G. (1994). The Iran policy trap. Foreign Policy, (96), 75-93. https://doi.org/10.2307/1149218

Slawson, N. (2016, January 2). Saudi execution of Shia cleric sparks outrage in Middle East. The Guardian. https://www.theguardian.com/world/2016/jan/02/saudiexecution-of-shia-cleric-sparks-outrage-in-middle-east

Tang, S. (2003, June 21). The rise of China as a security linchpin. Asia Times.

Tayyab, M., Afridi, S. A., \& Hamid, M. (2020). Sectarian Divide as a Cause of Protracted Conflict: A Case of Syria (2011-2018). Liberal Arts and Social Sciences International Journal (LASSIJ), 4(2), 294-305. https://doi.org/10.47264/idea.lassij/4.2.23

Waltz, K. N. (1979). Theories of international politics. Addison-Wesley Publishing.

Zahoor, M. \& Sadiq, N. (2021). Digital public sphere and Palestine-Israel conflict: A conceptual analysis of news coverage. Liberal Arts and Social Sciences International Journal (LASSIJ), 5(1), 168-181. https://doi.org/10.47264/idea.lassij/5.1.12

Zehra, S., Fatima, N., \& Khan, N. K. (2018). Iranian-Saudi Strategic Competition in the Middle East: An Analysis of the Arab Spring. Liberal Arts and Social Sciences International Journal (LASSIJ), 2(2), 59-66. https://doi.org/10.47264/idea.lassij/2.2.7

Zehra, S., Imtiaz, A., \& Jawad Ahmed (2020). Pakistan's Exertions of Reconciliation between Iran and Saudi Arabia: Challenges and Opportunities. Journal of Humanities, Social and Management Sciences, 1(1), 44-52. https://doi.org/10.47264/idea.jhsms/1.1.4

Zikriya, Khan, N., \& Salim, A. (2019). The Middle Eastern Dilemma: Pakistan's Role as Mediator for Conflict Resolution. Liberal Arts and Social Sciences International Journal (LASSIJ), 3(1), 9-18. https://doi.org/10.47264/idea.lassij/3.1.2 